\title{
MUTU DODOL PISANG BERDASARKAN SUBTITUSI BERBAGAI JENIS PISANG (Musa paradisiaca)
}

\section{Quality of Bananas Dodol By Substituting Different Types Of Bananas}

\author{
Elvis Eriyana 1), Husain Syam 2), Jamaluddin 3). \\ 1)Mahasiswa Program Studi Pendidikan Teknologi Pertanian FT UNM, \\ 2) dan 3)Dosen FT UNM \\ elviseriyana@gmail.com
}

\begin{abstract}
ABSTRAK
Penelitian ini bertujuan untuk mengetahui pengaruh subtitusi berbagai jenis pisang terhadap mutu dodol pisang dan juga untuk mengetahui mutu organoleptik dodol pisang. Penelitian ini menggunakan lima jenis pisang diantaranya pisang ambon, pisang barangan, pisang raja, pisang tanduk dan pisang kepok. Penelitian ini menggunakan rancangan acak lengkap (RAL) dan data dianalisis menggunakan mikrosoft excel dan SPSS versi 22. Parameter yang diamati dalam penelitian ini yaitu kadar air, kadar gula reduksi, mutu organoleptik sensorik dan hedonik. Hasil penelitian menunjukkan bahwa dodol pisang yang terbuat dari pisang ambon adalah yang terbaik dari hasil mutu maupun hasil uji organoleptik.
\end{abstract}

Kata Kunci : Mutu, Dodol Pisang.

\begin{abstract}
This study aims to determine the effect of substitution of various types of bananas on the quality of bananas dodol and also to determine the organoleptic quality bananas and also to determine the organoleptic quality dodol bananas. This study uses five types of bananas including ambon bananas, barangan of bananas, raja of bananas, tanduk of bananas and kepok of bananas. This study uses a completely randomized design CRD) and the data were analyzed using microsoft excel and SPSS version 22. The parameters observed in this study is the water content, reducing sugar and hedonic sensory organoleptic quality. The results showed that the banana dodol made from ambon of bananas is the best of the quality and organoleptic test results.
\end{abstract}

Keywords : Quality, Bananas Dodol

\section{PENDAHULUAN}

Buah-buahan merupakan salah satu sumber gizi lengkap dan sehat yang dibutuhkan manusia. Buah-buahan memiliki kandungan vitamin yang tinggi. Berbagai jenis buah-buahan yang tidak lepas dari masyarakat umum salah satunya adalah buah pisang. Pisang adalah buah yang sangat mudah ditemui dimana dan kapan saja, karena sifatnya yang dapat berbuah setiap saat tanpa menunggu musim seperti buah lainnya. Pisang merupakan tanaman yang berasal dari kawasan Asia Tenggara termasuk salah satunya adalah Indonesia. (Suyanti dan Supriyadi, 2008). Pisang menjadi buah yang sering dikonsumsi dibandingkan dengan buah 
lain karena mudah didapatkan dipasar serta dikonsumsi tanpa memperhatikan tingkatan sosial masyarakat Indonesia. Buah pisang ini menjadi kebutuhan orang banyak. Hal tersebut karena buah pisang merupakan salah satu buah yang mengandung sumber energi berupa karbohidrat dan air yang tinggi, mineral terutama kalium. Kandungan lain yang terdapat dalam buah pisang antara lain vitamin $A$, vitamin $B$ dalam bentuk thiamine, riboflavin, niacin, vitamin $\mathrm{B} 6$, folic acid. Selain itu, juga terkandung vitamin $\mathrm{C}$, magnesium, besi dan seng. Dengan demikian pisang juga merupakan salah satu bahan pangan yang mampu meningkatkan gizi masyarakat (Kasijadi, 2006).

Dalam proses pengolahan pisang menjadi produk lain yang perlu diperhatikan adalah jenis pisang yang digunakan. Jenis pisang yang digunakan sebagai subtitusi bahan pangan berpengaruh terhadap produk yang dihasilkan. Hal tersebut karena zat yang terkandung dalam buah pisang berbedabeda. Kandungan gizi pisang kepok berbeda dengan kandungan gizi pisang barangan, begitupun dengan jenis pisang lainnya misalnya pisang raja, pisang tanduk dan pisang ambon sehingga mempengaruhi produk olahan yang dihasilkan.

Berbagai jenis pisang yang digunakan sebagai subtitusi produk olahan akan menghasilkan produk yang berbeda dari sisi organoleptik. Pisang yang umum digunakan sebagai subtitusi produk olahan yaitu pisang kepok. Pisang kepok sering digunakan sebagai subtitusi karena apabila dikonsumsi tanpa diolah maka karakteristiknya agak keras dan rasa yang dimiliki kadang pekat serta tidak memiliki aroma yang khas sehingga konsumen kurang menyukai pisang kepok yang dikonsumsi tanpa diolah. Namun, adapula buah pisang yang sering dikonsumsi tanpa dilakukan pengolahan misalnya pisang ambon, pisang tanduk dan pisang susu. Pisang yang sering dikonsumsi tanpa diolah memiliki karakteristik yang lembut, aroma khas. Hal tersebut yang menyebabkan konsumen menyukai pisang tersebut walaupun tanpa diolah. Apabila jenis pisang yang memiliki karakteristik khas tersebut digunakan sebagai bahan subtitusi, maka akan mempengaruhi produk yang dihasilkan baik dari cita rasa, warna, aroma dan tekstur.

Selama beberapa waktu buah pisang tersebut akan mengalami proses kematangan. Kondisi tersebut menyebabkan perubahan kandungan gula dapat meningkatkan kandungan kadar air pada buah pisang. Selain kandungannya, selama proses pematangan buah pisang akan menghasilkan aroma khas sesuai dengan jenisnya. Dengan demikian, semakin matang buah pisang maka kandungan airnya akan semakin meningkat sehingga kerusakan akan semakin cepat yang dapat dilihat baik secara fisik maupun aroma yang dihasilkan. Kondisi demikian perlu dipikirkan untuk menemukan alternatif pengolahan buah pisang menjadi makanan ringan, cemilan bergizi dan dapat disimpan dalam waktu relatif lama. Salah satunya adalah dodol.

Dodol adalah makanan ringan atau jajanan yang banyak beredar di masyarakat. Dodol menjadi makanan tradisional yang cukup populer di Indonesia. Dodol diklasifikasikan menjadi dua yaitu dodol yang diolah dari tepungtepungan dan dodol yang diolah dari buah-buahan. Dodol buah-buahan yang biasa ditemui yaitu dodol apel, dodol stroberi, dodol pepaya dan dodol pisang. 
Penambahan buah-buahan dalam
pembuatan dodol bertujuan untuk
menambah cita rasa dodol yang
dihasilkan. Pada umumnya, buah-
buahan yang ditambahkan dalam proses
pembuatan dodol adalah buah-buahan
yang cepat rusak dan membutuhkan
pengolahan lebih cepat agar dapat
bertahan lama. Dodol yang dibuat
dengan penambahan buah-buahan
diharapkan mampu menghasilkan rasa
manis, gurih dan legit. Penambahan
pisang ini selain untuk memperpanjang
daya simpan buah pisang juga untuk
meningkatkan daya gunanya yaitu
diversifikasi produk dengan
mengolahnya menjadi dodol pisang
dengan memilih jenis pisang yang cocok
dijadikan bahan subtitusi dodol yang bisa
diterima masyarakat secara organoleptik.

Pengolahan dodol dengan menggunakan bahan tambahan pisang diharapkan mampu menghasilkan tekstur dodol menjadi lunak dan kaya akan serat, warna dodol yang coklat, aroma khas dodol, rasa dodol khas pisang dan dapat meningkatkan nilai gizi dodol yang pada umumnya hanya berbahan dasar ketan, gula merah dan santan. Pengolahan dodol dengan penambahan berbagai jenis pisang yang berbeda diduga akan menghasilkan dodol pisang yang berbeda pula. Dalam penelitian Muhammad lqbal (2012), dodol yang dibuat dengan menggunakan pisang kepok dengan variabel konsentrasi gula merah yang digunakan yaitu $20 \%, 30 \%$, $40 \%$ dan $50 \%$ sehingga diperoleh hasil penelitan bahwa gula memberikan pengaruh terhadap dodol pisang namun pada penelitian ini hanya menggunakan satu jenis pisang yaitu pisang kepok sehingga perlu dilakukan penelitian dengan jenis pisang yang berbeda sehingga adanya perbandingan jenis pisang yang menjadi subtitusi dodol tersebut.

Penambahan buah pisang pada pembuatan dodol ini akan mempengaruhi kadar gula dan kadar air pada dodol yang dihasilkan. Buah pisang yang ditambahkan mengandung gula fruktosa sementara dalam pembuatan dodol ditambahkan gula merah yang mengandung gula sukrosa. Penambahan kedua jenis gula tersebut menghasilkan gula reduksi pada dodol. Kandungan gula reduksi pada dodol yang dihasilkan akan berbeda-beda sesuai dengan jenis pisang yang ditambahkan. Berdasarkan SNI dodol, gula reduksi dodol yang diinginkan yaitu minimal $40 \%$. Sehingga perlu untuk meneliti jenis pisang yang mampu menghasilkan dodol pisang sesuai SNI serta dapat diterima secara organoleptik oleh konsumen.

Secara umum, penelitian ini bertujuan untuk menemukan jenis pisang yang tepat digunakan sebagai bahan subtitusi dodol. Jenis pisang yang baik akan dijadikan rekomendasi pada produsen dodol untuk dijadikan bahan subtitusi sehingga menghasilkan dodol yang dapat diterima konsumen berdasarkan organoleptik dodol pisang yang berpedoman pada Standar Nasional Indonesia (SNI).

\section{TUJUAN PENELITIAN}

Penelitian ini bertujuan untuk mengetahui pengaruh subtitusi berbagai jenis pisang terhadap kadar air, kadar gula reduksi dan mutu organoleptik dodol pisang.

\section{METODE PENELITIAN}

Jenis penelitian ini adalah penelitian kuantitatif dengan pendekatan eksperimen. Rancangan percobaan yang 
digunakan yaitu rancangan acak lengkap dengan perlakuan penambahan berbagai jenis pisang yaitu pisang ambon, pisang barangan, pisang raja, pisang tanduk dan pisang raja.

Alat-alat yang digunakan dalam pembuatan produk adalah pisau, timbangan, pengaduk, blender, wadah, wajan, kompor, panci, kain saring. Pada uji kadar gula reduksi alat yang digunakan yaitu timbangan digital, gelas ukur, erlenmeyer, pipet, tabung reaksi, reflux dan alat titrasi. Pada pengujian kadar air alat yang digunakan yaitu oven, timbangan digital dan cawan.

Alur proses pembuatan dodol pisang yaitu kelima jenis pisang yang digunakan terlebih dahulu dilakukan uji kadar gula reduksi kemudian dibuat produk dodol melalui proses pemasakan santan $500 \mathrm{ml}$, tepung ketan $50 \mathrm{~g}$, gula merah $200 \mathrm{~g}$, susu bubuk $35 \mathrm{~g}$, vanili $25 \mathrm{~g}$ kemudian diaduk hingga rata, selanjutnya setelah rata kemudian ditambahkan bubur pisang sesuai jenis pisang yang digunakan, aduk secara terus menerus selama satu jam hingga dodol menjadi kalis.

Selanjutnya dilakukan uji kadar air dengan menggunakan metode oven vacum, uji gula reduksi dengan menggunakan metode luff schroll, uji organoleptik dengan menggunakan uji sensorik dan uji hedonik.

Penelitian ini dilaksanakan di Laboratorium Pendidikan Teknologi Pertanian Fakultas Teknik Universitas Negeri Makassar dan Laboratorium Kimia Fakultas MIPA Universitas Negeri Makassar.

Data pada penelitian yang diperoleh dari hasil pengujian kadar air, kadar gula reduksi dan organoleptik. Karakteristik organoleptik dengan menggunakan metode uji sensorik (mutu) dan uji hedonik (kesukaan) yang dilakukan dengan menguji seberapa jauh tingkat kesukaan panelis terhadap karakteristik dodol yang meliputi tekstur, cita rasa, warna dan aroma. Panelis yang dilibatkan dalam pengujian ini yaitu panelis semi terlatih (semi-trained panel) yang terdiri dari 25 orang dari kalangan mahasiswa. Data yang diperoleh dianalisis menggunakan ANOVA yang dilanjutkan denga uji lanjut duncan taraf 95\%.

\section{HASIL DAN PEMBAHASAN}

\section{Kadar Air}

Berdasarkan hasil uji kadar air menggunakan metode oven vacum, hasil pengujian dapat dilihat pada gambar 1 .

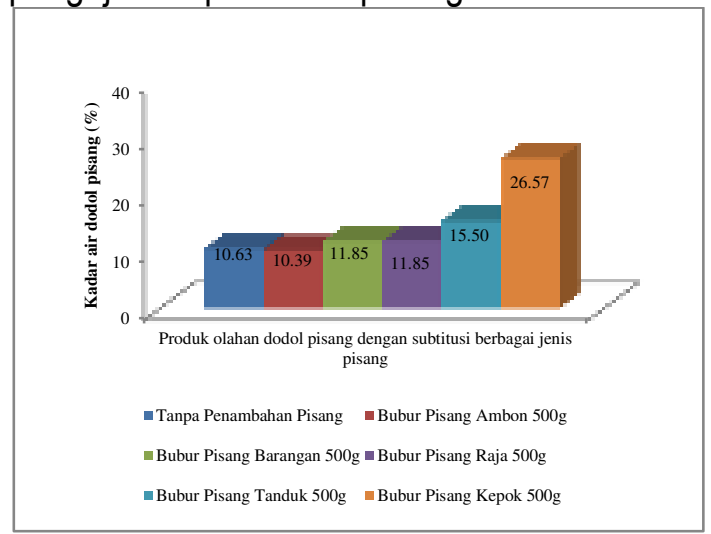

Gambar 1

Kadar air dodol pisang

Dari hasil pengamatan menunjukkan bahwa kadar air dodol pisang pada berbagai penambahan berbagai jenis pisang memiliki nilai ratarata yang berbeda-beda. Hasil analisis sidik ragam menunjukkan bahwa setiap perlakuan memberikan pengaruh yang sangat nyata terhadap perubahan kadar air dodol pisang.

Hasil uji lanjut duncan memperlihatkan bahwa perlakuan penambahan pisang ambon, pisang barangan dan pisang raja merupakan perlakuan yang terbaik karena memenuhi standar mutu dodol yaitu 
kadar air dibawah 20\%. Menurut Desrosier (1998), bahwa kadar air produk pangan dipengaruhi oleh suhu pemasakan. Lebih lanjut dijelaskan oleh Mussaddad \& Hartuti (2003) dan Susilorini \& Errysamitri (2006) bahwa dodol pada umumnya berkadar air 10$40 \%$. Selain itu, kadar air dodol pisang dipengaruhi oleh penambahan tepung beras dan penambahan subtitusi bahan lain yang mengandung pati. Pernyataan tersebut diperkuat Haryadi (2006), bahwa tepung beras ketan pada pemanasan dengan keberadaan cukup banyak air, menyebabkan pati yang terkandung dalam tepung akan menyerap air dan membentuk pasta yang kental dan pada saat dingin membentuk massa yang kenyal, lenting dan liat.

\section{Kadar Gula Reduksi}

Hasil pengujian kadar gula reduksi dodol piang yang menggunakan metode luff schroll dapat dilihat pada gambar 2 .

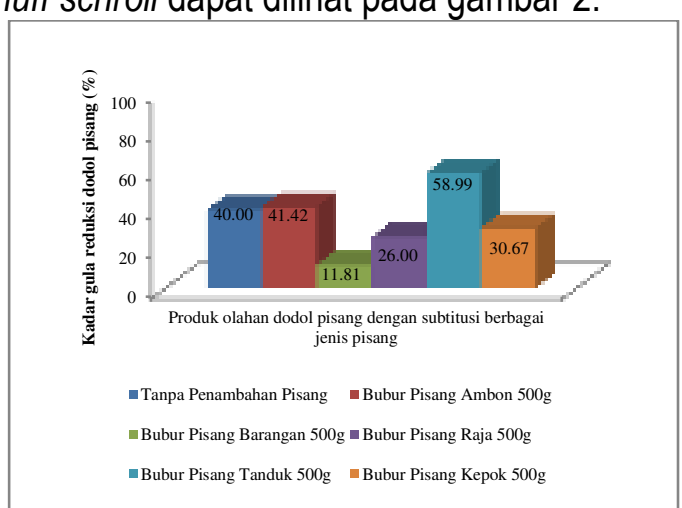

Gambar 2

Kadar gula reduksi dodol pisang

Dari gambar 2 dapat dilihat bahwa dodol pisang yang memenuhi standar kadar gula reduksi yaitu pisang ambon dan pisang tanduk. Sementara pisang barangan, pisang raja dan pisang kepok tidak memenuhi standar mutu dodol berdasarkan parameter gula reduksi karena dibawah $40 \%$.
Dari hasil penelitian tersebut menunjukkan bahwa kadar gula reduksi akan meningkat dari pisang yang diolah menjadi dodol pisang. Peningkatan signifikan terjadi pada pisang ambon dan pisang tanduk. Sementara pisang barangan, pisang raja dan pisang kepok tidak mengalami peningkatan kadar gula reduksi yang signifikan. Faktor utama yang mempengaruhi perubahan gula reduksi pada bahan pangan yaitu pemanasan, gugus keton, gugus aldehid dan kadar gula pereduksinya. Pada saat pemanasan gula pereduksi mereduksi semua gula-gula yang terkandung dalam bahan pembuatan dodol. Gula pereduksi tersebut mengandung gugus aldehid dan keton yang mereduksi gula yang terkandung dalam bahan pangan (Fany, 2009). Selain itu, pemanasan mampu membantu pereduksian pada dodol pisang. Dimana pemanasan mampu membantu proses metabolisme yang menguraikan gula reduksi yang terkandung pada buah pisang. Sehingga walaupun bahan dasar sama tetapi jenis berbeda maka menghasilkan kadar gula reduksi pisang yang berbeda.

\section{Warna}

Warna dodol pisang berdasarkan penambahan berbagai jenis pisang dilihat pada gambar 3 .

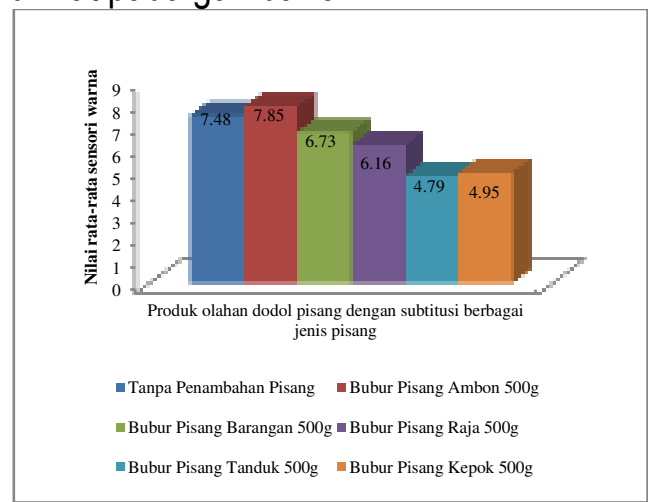

Gambar 3

Warna dodol pisang 
Hasil uji hedonik warna seperti pada gambar 3 menunjukkan penilaian panelis yang paling tinggi terdapat pada perlakuan penambahan pisang ambon yang memperoleh penilaian dengan interval agak suka menghampiri suka. Dodol pisang barangan, pisang raja dan pisang kepok juga memperoleh penilaian agak suka sedangkan dodol pisang tanduk memperoleh penilaian kurang suka.

Hal yang berpengaruh terhadap warna dodol yang dihasilkan salah satunya yaitu penambahan berbagai jenis pisang. Pisang mengandung gula reduksi yang mampu bereaksi pada saat proses pemanasan yang akan menghasilkan warna cokelat pada produk dodol (browning). Perubahan warna menjadi cokelat pada produk tersebut terjadi karena reaksi karamelisasi yang terjadi pada gulagula saat pemasakan. Kualitas warna yang baik pada dodol adalah warna cokelat. Hal tersebut dikemukakan oleh margareta (2013) bahwa "dodol yang berwarna cokelat terutama akibat penambahan gula yang bereaksi dengan protein (menghasilkan reaksi pencokelatan non-enzimatis) serta akibat reaksi karamelisasi dari gula". Menurut Apandi(1984), warna cokelat merupakan suatu proses reaksi browning melalui jalannya reaksi mailard dan karamelisasi. Reaksi mailard terjadi jika gula dipanaskan diatas titik lelehnya dan berubah warna menjadi cokelat disertai dengan penambahan cita rasa.

\section{Tekstur}

Tekstur dodol pisang berdasarkan penambahan berbagai jenis pisang dilihat pada gambar 4 .

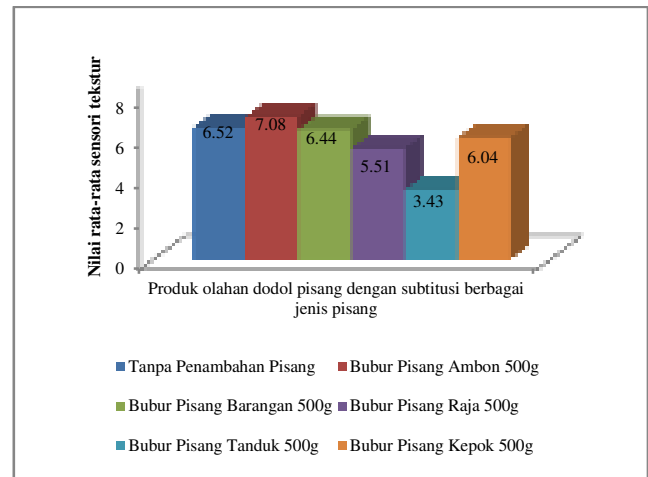

\section{Gambar 4}

Tekstur dodol pisang

Tekstur dodol pisang terbaik yang dihasilkan yaitu dengan penambahan pisang ambon dengan penilaian normal. Sementara dodol pisang barangan, pisang raja dan pisang kepok memperoleh penilaian cukup normal. Sedangkan dodol pisang tanduk memperoleh penilaian kurang normal.

Pada gambar 4 tersebut diartikan bahwa dodol tanpa penambahan pisang menghasilkan penilaian antara cukup normal hingga normal. Dodol pisang ambon memperoleh penilaian normal, dodol pisang barangan memperoleh penilaian cukup normal, dodol pisang raja memperoleh penilaian cukup normal, dodol pisang tanduk memperoleh penilaian kurang normal dan dodol pisang kepok menghasilkan penilaian yang mendekati angka normal. Dari data tersebut dapat disimpulkan bahwa dodol yang dikatakan normal yaitu memperoleh penilaian diatas 5 . Dodol dengan penambahan pisang ambon adalah dodol yang memiliki penilaian tertinggi sedangkan dodol dengan penambahan pisang tanduk merupakan dodol yang memiliki penilaian terendah yaitu dibawah 5 sehingga dikatakan tidak normal.

Tekstur dodol yang dihasilkan adalah kalis hingga lembek. Dodol yang memiliki tekstur kalis yaitu dengan 
penambahan pisang ambon, pisang barangan, pisang raja dan pisang kepok yang dinilai normal oleh panelis sedangkan dodol dengan penambahan pisang tanduk memiliki tekstur yang lembek sehingga dikatakan tidak normal. Teksur dodol tersebut dipengaruhi oleh bahan baku, pemanasan, kadar air dan aktivitas air. Purnomo (1995), menjelaskan bahwa kadar air dan aktivitas air dalam bahan pangan sangat besar peranannya terhadap tekstur yang dihasilkan. Tekstur dodol pisang juga dipengaruhi oleh kandungan air bahan tambahnya. Semakin matang buah pisang yang digunakan maka tekstur dodol juga berbeda. Sehingga dalam membuat dodol pisang kematangan pisang yang baik adalah kematangan sempurna. Dimana gula dan kandungan airnya tidak berlebih sehingga dodol yang dihasilkan juga normal. Selain itu, tekstur dodol pisang dipengaruhi oleh penambahan tepung ketan. Dalam penelitian ini konsentrasi tepung ketan yang digunakan yaitu $50 \mathrm{~g}$. Hal tersebut karena pisang yang digunakan juga mengandung pati sehingga ketan yang digunakan hanya $1 / 10$ dari santan. Hal ini sesuai pendapat siswoputranto (1998) bahwa tepung beras ketan mengandung amilopektin yang menghasilkan sifat kental pada dodol pisang sehingga membentuk tekstur yang elastis dan kalis. Sehingga dalam pembuatan dodol, tepung ketan yang digunakan tidak boleh terlalu banyak dan tidak boleh terlalu sedikit serta disesuaikan dengan bahan tambahan misalnya buah pisang.

\section{Aroma}

Aroma dodol pisang berdasarkan penambahan berbagai jenis pisang dilihat pada gambar 5 .

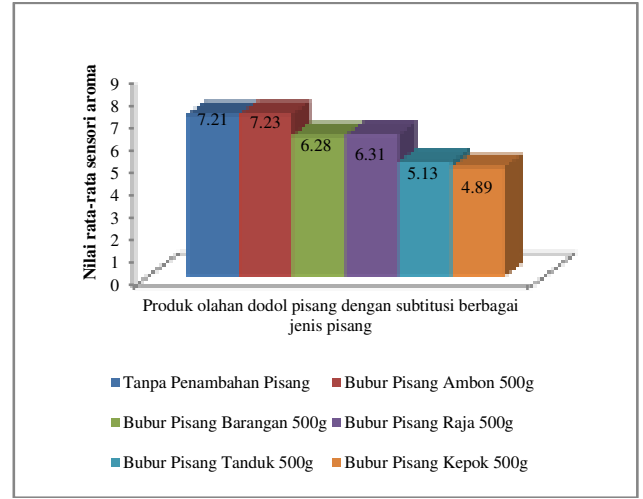

Gambar 5

Aroma dodol pisang

Dari hasil penilaian uji sensorik panelis diperoleh nilai mutu dodol pisang yang dihasilkan. Hasil penilaian panelis yaitu dodol pisang ambon memperoleh nilai normal, dodol pisang barangan menghasilkan penilaian cukup normal, dodol pisang tanduk menghasilkan penilaian kurang normal dan dodol pisang kepok memperoleh penilaian menghampiri normal. Secara keselurhan bahwa dodol pisang dengan penambahan kelima jenis pisang tersebut dinilai dari parameter aroma dikatakan normal. Rata-rata penilaian panelis yaitu 4,89 hingga 7,23 yang diterjemahkan bahwa penilaian tersebut normal. Dodol pisang dengan nilai tertinggi yaitu dodol pisang ambon dan penilaian terendah yaitu dodol pisang kepok.

Aroma yang diinginkan dodol pisang berdasarkan SNI yaitu normal. Skala normal yaitu apabila produk berbau khas. Normalitas dodol berdasarkan SNI yaitu berbau khas dodol dan bahan tambahan lainnya. Dodol pisang dikatakan normal apabila berbau khas dodol dengan aroma santan, gula merah dan tepung ketan serta aroma khas bahan tambah yaitu pisang. Menurut lqbal (2012) semakin tinggi konsentrasi gula maka rasa dan aroma yang dihasilkan semakin tinggi. 
Hal ini karena semakin banyak gula yang ditambahkan maka rasa dan aroma dari dodol semakin disukai oleh panelis. Dengan penambahan gula akan terbentuk karamel yang membuat rasa dan aroma dodol lebih enak, lebih tajam sehingga rasa dan aroma dodol lebih disukai. Karamelisasi disebabkan oleh reaksi gula pereduksi dengan gugus amina primer atau pemakaian suhu tinggi pada sukrosa. Pencoklatan ini sengaja dibuat untuk menimbulkan bau dan cita rasa yang dikehendaki.

Penambahan gula merah pada dodol yang dapat memperkuat aroma pada dodol dengan kolaborasi berbagai jenis pisang yang digunakan sebagai bahan utama dalam pembuatan dodol. Selain itu, pengolahan dengan suhu tinggi membuat seyawa volatil rusak dan menguap sehingga mempengaruhi penilain panelis terhadap aroma dodol yang dihasilkan. Hal ini sesuai dengan pendapat Apandi (1984), bahwa adanya senyawa volatil pada buah dapat memberikan aroma yang khas.

Senyawa volatil pada buah dapat memberikan aroma yang khas. Senyawa volatil ini merupakan persenyawaan terbang yang sekalipun dalam jumlah kecil namun sangat berpengaruh pada flavour. Kebanyakan merupakan esterester alkohol alifatis juga aldehid, keton dan lain-lain. Produksi zat-zat ini biasanya dimulai pada masa klimaterik dan dilanjutkan pada proses penuaan (Apandi, 1984).

\section{Rasa}

Rasa dodol pisang berdasarkan penambahan berbagai jenis pisang dilihat pada gambar 6 .

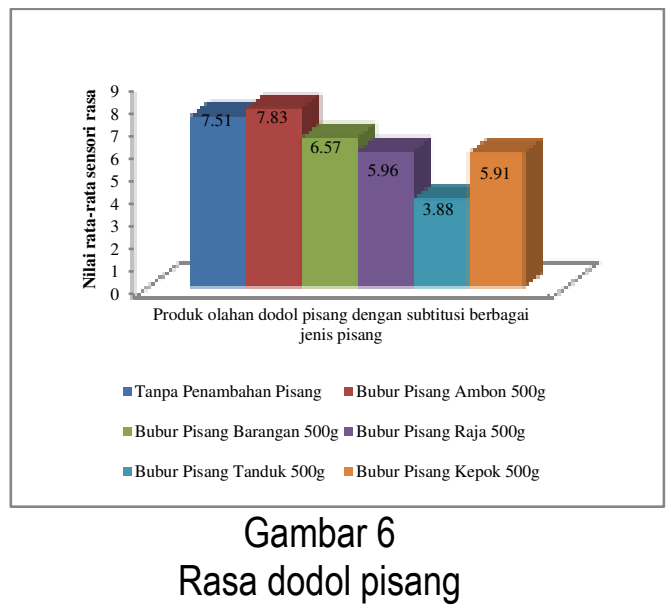

Penilaian panelis terhadap rasa dodol terlihat pada gambar yaitu dodol tanpa penambahan pisang dan pisang ambon memperoleh penilaian normal, dodol pisang barangan, dodol pisang raja dan dodol pisang kepok memperoleh penilaian antara cukup normal hingga normal sedangkan dodol pisang tanduk memperoleh penilaian kurang normal. Dari keenam sampel tersebut disimpulkan bahwa dodol pisang ambon mendapat penilaian tertinggi panelis sedangkan nilai dodol pisang tanduk mendapat penilaian terendah dari panelis.

Rasa dodol pisang yang dihasilkan dipengaruhi oleh gula dan penambahan berbagai jenis pisang. Dengan penambahan gula merah sebanyak $200 \mathrm{~g}$ dan pisang ambon $500 \mathrm{~g}$ adalah rasa terbaik. Hal ini disebabkan karena penambahan gula merah dengan jumlah yang tepat disesuaikan dengan bahan tambahan manis berupa pisang akan menghasilkan dodol yang memiliki rasa manis yang tepat.

Buah pisang mengandung gula reduksi. Pada awal pertumbuhan buah konsentrasi gula total, gula reduksi dan bukan reduksi sangat rendah. Tetapi saat proses pemasakan, gula total meningkat tajam dalam bentuk glukosa dan fruktosa. Naiknya kadar gula yang 
tiba-tiba ini dapat digunakan sebagai indeks kimia kemasakan (Lodth dan Pantastico, 1975). Selanjutnya pernyataan tersebut didukung oleh Idrus (1994), bahwa gula yang digunakan harus dalam jumlah yang tepat dan sesuai dengan ukuran. Penggunaan gula yang kurang juga akan mengakibatkan dodol dengan rasa kurang manis. Selanjutnya menurut Winarno (2004), rasa juga dipengaruhi oleh beberapa faktor yaitu senyawa kimia, suhu, konsentrasi dan interaksi dengan komponen rasa yang lain.

\section{KESIMPULAN}

Kesimpulan yang dapat diperoleh dari hasil penelitian adalah sebagai berikut:

1. Penambahan buah pisang pada pembuatan dodol pisang memberikan pengaruh nyata terhadap organoleptik dodol pisang yang dihasilkan. Dodol pisang dengan penambahan pisang ambon merupakan perlakuan terbaik pada parameter warna, aroma, tekstur dan rasa yang dihasilkan.

2. Penambahan buah pisang pada pembuatan dodol pisang memberikan pengaruh yang nyata terhadap kadar air dan kadar gula reduksi dodol yang dihasilkan. Dodol pisang dengan penambahan pisang ambon merupakan perlakuan terbaik pada parameter kadar air dan kadar gula reduksi yang dihasilkan.

\section{DAFTAR PUSTAKA}

Apandi, M., 1984. Teknologi Buah dan Sayur. Alumni. Bandung

Fany. 2009. Metode luff schroll. Error! Hyperlink reference not valid. lqbal Muhammad, Misril Fuadi dan Winda Astari Putri Pulungan. 2012. Studi Pembuatan

Dodol Pisang (Musa paradisiaca L). Jurnal Agrium Oktober 2012 Volume 17

No. 3. Program Studi IImu dan Teknologi

Fakultas Pertanian.

Universitas Muhammadiyah Sumatera Utara.

Kasijadi, F. 2006. Penerapan Agribisnis Berbasis Pisang Spesifikasi Lokalisasi Pisang Mas dan Agung. Pertanian BB2TP. BPTP Jawa Timur.

Margareta, P. 2013. Eksperimen Pembuatan Dodol Ganyong Komposit Dengan Tepung Ketan Putih Penambahan Sari Buah Parijoto. Skripsi. Semarang: Fakultas Teknik. Universitas Negeri Semarang. Purnomo, H. 1995. Aktifitas Air dan Peranannya dalam Pengawetan Pangan. Ul-Press, Jakarta.

Siswoputranto. 1998. Kopi Internasional dan Indonesia. Kanisius, Yogyakarta.

Winarno. F.G. 2004. Pengantar Teknologi Pangan. PT. Gramedia. Jakarta. 